Corresponding Author: Hilman Mulyana; email:

hilman.mulyana@bku.ac.id

Published: 7 February 2022

Publishing services provided by

Knowledge E

(c) Hilman Mulyana and

Nurhaliza Rahmatalia. This

article is distributed under the

terms of the

Attribution License, which

permits unrestricted use and redistribution provided that the

original author and source are credited.

Selection and Peer-review under the responsibility of the IVCN Conference Committee.

\section{Effect of Health Education Based on the Health Belief Model on Family Knowledge About Covid-19 in Mothers Who Have Children With Stunting}

\section{Hilman Mulyana* and Nurhaliza Rahmatalia}

Nursing Faculty, Bhakti Kencana University, JI. RE. Martadinata, No. 142, Tasikmalaya City, West Java - Indonesia

\section{ORCID}

Hilman Mulyana: https://orcid.org/0000-0002-1816-4607

Abstract. The high numbers of Covid-19 cases have been due to the lack of knowledge of, public awareness of, and compliance with the health protocols. This has led to various perceptions among the public and resulted in people's poor behavior. The danger of Covid-19 is certainly very worrying, especially for high-risk groups, such as small children with stunting conditions. The Health Belief Model provides a template for how to identify maternal knowledge about diseases and decision-making processes in finding health services. This study aimed to determine the effect of health education based on the Health Belief Model on family knowledge about Covid-19 in mothers who have children with stunting in the village of Jayaratu, Sariwangi District, Tasikmalaya Regency in 2021. This was a descriptive study with a one group pretest-posttest design. There were 36 participants, who were families with children who have stunting. The data collection instrument was a questionnaire in Google Forms, which had been validated. The paired t-test was used for analysis. The results of the study showed that family knowledge about Covid-19 increased, as did family perceptions, after being given health education ( $p<0.001$ ). We can conclude that health education based on the Health Belief Model can influence knowledge about Covid-19 in mothers with a child who has stunting. The results of this study are expected to be a reference in efforts to reduce the prevalence of people infected with Covid- 19.

Keywords: Covid-19 knowledge, health education, Health Belief Model (HBM)

\section{Introduction}

Novel Coronavirus or better known as 2019-NCOV first appeared in Wuhan, China at the end of 2019 and the whole world was surprised by the emergence of the Corona virus outbreak that infected 223 countries in the world. World Health Organization (WHO) (2020) establishes Covid-19 as a global pandemic in March 2020 and has stated as an emergency of public health on January 30, 2020. The determination of this pandemic is based on significantly developing cases and sustainable cases (1). 
Data Situation Report Covid-19 to 05 April 2021, 145,240,343 Covid-19 cases are confirmed including 3,082,137 cases of death, 106,234,345 patients declared recovered and there are $22,836,759$ active cases throughout the world. The highest case is found in the United States with a total of 31,383,126 cases confirmed by the addition of the number of 70285 cases per day and the case of death amounts to 568,513 people (2).

Likewise with the number of Covid-19 cases in Indonesia until April 23, 2021, there were 1,632,248 cases confirmed, 1,487,369 cases of Austen Covid-19, 44,346 cases of death, and 100,533 active cases until now (8). The highest case in Indonesia according to the Covid-19 handling task force until April 23, 2021, was occupied by DKI Jakarta with a number of cases of 403,260 (24.7\%), then continued with West Java Province with a case of 273.135 (16.7\%) confirmed case, 239,551 people which has healed, 3,592 cases of death and 28,926 are still in care or isolation (1).

Tasikmalaya Regency is one of the districts in West Java, until now on April 24, 2021, recorded 3,066 Covid-19 cases, patients healed amounting to 2,921 people, 109 cases of death, and 36 people who were still in care or isolation (3). On April 30, 2021, the highest case in Tasikmalaya Regency is in Sariwangi District with a total of 440 positive cases, patients who recovered 407 people, cases of death there were 9 people and who were still in the care or independent isolation of 24 people. The data was taken through a preliminary study by conducting interviews with Sariwangi Health Center surveillance. Including the highest village of cases in Sariwangi Subdistrict, namely in Jayaratu Village with a number of cases of 71 people, this data was taken based on data at Sariwangi Health Center.

Covid-19 is an infectious disease caused by the Coronavirus novel (2019-ncov). This virus will attack a mild to the moderate respiratory system, they can recover without requiring special care. People with comorbid diseases are more likely to develop diseases and the best ways to prevent and slow transmission is to know well about the virus, how to transmit, how to prevent, and how to treat it (1).

Someone can contract Covid-19 just by breathing drops directly from a positive patient or by touching the surface contaminated by the virus and then touching his own face, this can also be the process of transmission. The danger of Covid-19 and this behavior is certainly very worrying, especially for high-risk groups, such as small children or toddlers with relatively weak body resistance and with stunting conditions (4).

Children with growth and normal development are still very likely exposed to Covid19, as evidenced by cases in children's categories in several countries. Children with stunting conditions are highly valued through good food intake to prevent the condition worse and can maintain endurance. The stunting case from 25.6\% in 2015 was 38\% 
in 2019 , which meant that it increased by around $12.4 \%$ in 5 years. Tasikmalaya City is one of the cities in West Java Province. For all children born in 2019, the prevalence of stunting increased from $10.8 \%$ to $10.95 \%$. As a result of the impact of Pandemic Covid19 is expected to increase by 2020-2021 (4).

Based on the data above, the health belief model (Health Belief Model) is the method used to explain how healthy people and pain are looking for information to avoid disease. This model provides tools to identify community knowledge about diseases and decision-making processes in seeking health services. In this theory a person's perception of sensitivity, treatment, and healing influences decision making to behave healthy (6).

Research Becker (10) regarding HBM states that every individual must have a willingness to participate in the intervention or health behavior based on a positive perception that health is a very valuable result. Therefore, this can predict if someone does health behavior by determining perceptions of illness, pain, or accident, identifying modifier factors, and a person's tendency to act (7).

Research on health education on disease and knowledge is often studied using the HBM method. One of them is literature research conducted by Saprudin, N. State. A. P., \& Guntara, B, which examines the effect of HBM Health Education on the level of knowledge and attitudes of the mother in the provision of pentavalent immunization, states the results of the ministry's research on average before health education is 27.05 with a standard deviation of 2.683. After the mother was given the average health education of the mother's attitude of 30.71 with a standard deviation of 2.326. And showing the significance value obtained by $0.0001(\mathrm{p}<0.05)$, then $\mathrm{H} 1$ failed to be rejected then it could be concluded that there was an influence between HBM health education on the attitude of the mother in the administration of pentavalent immunization in children (15).

Then the researcher conducted a preliminary study through interviews with 7 families and found that there were 4 families who were still had minimal knowledge about Covid-19 and lack of trust in the presence of pandemic and 3 other families expressed understanding. These problems usually need an explanation to find ways of solving and to know and learn the way someone to ask for medical help. These patterns are known as the confidence model for health services (health belief models).

Based on these phenomena researchers are interested in conducting research with the title "Effect of Health Belief Model Health Education (HBM) on family knowledge about Covid-19 in mothers who have stunting children". 


\section{Materials and Methods}

This research is a quantitative study using a descriptive research method with One Group Pretest Posttest. The population in this study family had children stunting and had been diagnosed with Covid-19. The sample used in this study amounted to 36 families. Sampling techniques use total sampling. The study was conducted after obtaining an Ethical Clearance approval with the approval number of B/O70/325/Wasda by taking into account the research ethics principle.

In this study, researchers collected data based on HBM health education as independent variables. The independent variable is obtained from the data source using the questionnaire, with the properties of quantitative data and ordinal measurement scales. For the dependent variable data, namely Knowledge of Keluaga about Covid-19, researchers used secondary data collected from Sariwangi Health Center surveillance and local cadres. This is quantitative data with a nominal measurement scale.

SPSS: This stage is with a computerized system starting with editing stages, coding, tabulating, and data entry. Then the next data were analyzed using univariate analysis used to obtain an image of analysis, distribution, frequency, and presentation of each variable based on HBM health education variables. Bivariate analysis was used to examine the relationship between HBM health education with family knowledge of Covid-19 in mothers who have stunting children, and tested statistics used in this study, namely the Paired Test Test (T-test).

\section{Result}

The results of the univariate analysis

This analysis is used to describe the variables studied, in this study the variables are taken in univariate analysis, namely knowledge of Covid-19 and 6 dimensions of HBM. The following results research described below:

Source: Research Primary Data, 2021

\subsection{Bivariate Analysis Results}

The analysis used to test the effect between the two variables used has a relationship or correlation. This analysis serves to determine the effect of HBM health education on family knowledge about COVID-19. To determine whether there is an effect of the 
TABLE 1: Frequency distribution of family knowledge about Covid-19 before and after intervention

\begin{tabular}{|c|c|c|c|c|c|c|c|}
\hline \multirow[t]{2}{*}{ Category } & \multicolumn{3}{|c|}{ Health Education HBM pretest } & \multicolumn{3}{|c|}{ Health Education HBM posttest } & \multirow[t]{2}{*}{ Total } \\
\hline & Good & Enough & $\begin{array}{l}\text { Not } \\
\text { enough }\end{array}$ & Good & Enough & $\begin{array}{l}\text { Not } \\
\text { enough }\end{array}$ & \\
\hline Knowledge & $\begin{array}{l}13 \\
(36,1 \%)\end{array}$ & 7 (19,5\%) & $\begin{array}{l}16 \\
(44,4 \%)\end{array}$ & 27 (75\%) & & 9 (25\%) & $\begin{array}{l}36 \\
(100 \%)\end{array}$ \\
\hline $\begin{array}{l}\text { Vulnerability } \\
\text { perception }\end{array}$ & 9 (25\%) & $\begin{array}{l}10 \\
(27,8 \%)\end{array}$ & $\begin{array}{l}17 \\
(47,2 \%)\end{array}$ & 9 (25\%) & $\begin{array}{l}19 \\
(52,8 \%)\end{array}$ & $8(22,2 \%)$ & $\begin{array}{l}36 \\
(100 \%)\end{array}$ \\
\hline $\begin{array}{l}\text { Perception } \\
\text { of } \\
\text { seriousness }\end{array}$ & $\begin{array}{l}23 \\
(63,8 \%)\end{array}$ & - & $\begin{array}{l}13 \\
(36,2 \%\end{array}$ & $\begin{array}{l}32 \\
(88,9 \%\end{array}$ & - & $4(11,1 \%)$ & $\begin{array}{l}36 \\
(100 \%)\end{array}$ \\
\hline $\begin{array}{l}\text { Perception } \\
\text { of benefits }\end{array}$ & $\begin{array}{l}20 \\
(55,6 \%)\end{array}$ & - & $\begin{array}{l}16 \\
(44,4 \%)\end{array}$ & $\begin{array}{l}24 \\
(66,7 \%)\end{array}$ & - & $12(33,3 \%)$ & $\begin{array}{l}36 \\
(100 \%)\end{array}$ \\
\hline $\begin{array}{l}\text { Obstacle } \\
\text { perception }\end{array}$ & $\begin{array}{l}20 \\
(55,6 \%\end{array}$ & - & $\begin{array}{l}16 \\
(44,4 \%)\end{array}$ & $\begin{array}{l}24 \\
(66,7 \%)\end{array}$ & - & $12(33,3 \%)$ & $\begin{array}{l}36 \\
(100 \%)\end{array}$ \\
\hline $\begin{array}{l}\text { Motivation to } \\
\text { be healthy }\end{array}$ & $\begin{array}{l}20 \\
(55,6 \%)\end{array}$ & - & $22(61,1 \%)$ & $22(61,1 \%)$ & - & $14(38,9 \%)$ & $\begin{array}{l}36 \\
(100 \%)\end{array}$ \\
\hline Action cue & $\begin{array}{l}11 \\
(30,6 \%)\end{array}$ & $9(25 \%)$ & $\begin{array}{l}16 \\
(44,4 \%)\end{array}$ & $\begin{array}{l}13 \\
(36,1 \%)\end{array}$ & $\begin{array}{l}19 \\
(52,8 \%)\end{array}$ & $4(11,1 \%)$ & $\begin{array}{l}36 \\
(100 \%)\end{array}$ \\
\hline
\end{tabular}

TABLE 2: Summary of Statistical Test Results

\begin{tabular}{|c|c|c|c|c|c|c|}
\hline Category & $\begin{array}{l}\text { Mean } \\
\text { Pretest }\end{array}$ & $\begin{array}{l}\text { Mean } \\
\text { Posttest }\end{array}$ & SD Pretest & $\begin{array}{l}\text { SD } \\
\text { Posttest }\end{array}$ & Correlation & $P$ value \\
\hline $\begin{array}{l}\text { The effect of } \\
\text { HBM health } \\
\text { education on } \\
\text { family knowledge } \\
\text { about COVID-19 }\end{array}$ & 8,64 & 10,61 & 1,437 & 0,728 & 0,190 & 0,000 \\
\hline
\end{tabular}

independent variable on the dependent variable in this study using the T-test with the following results:

\section{Discussion}

Based on the results of a univariate study of family knowledge about COVID-19 pretest before the HBM health education was conducted, it was found that 13 families had good knowledge (36.1\%), 7 families had sufficient knowledge (19.5\%) and 16 families had poor knowledge (44.4\%). Seeing these data illustrates that family knowledge about COVID-19 in mothers who have stunting children has more or less knowledge.

Knowledge about COVID-19 includes things that must be done, one of which is washing hands with the right soap, symptoms of COVID-19, modes of transmission, and readiness to adapt to new habits (IMR) or new normal. Because knowledge is one of 
the main sources that families must know, in order to prevent COVID-19, which is easily transmitted.

The results of the post-test research after the HBM health education was carried out, it was found that the results of knowledge increased with the value of the good category totaling 27 respondents (75\%) indicating good knowledge and 9 respondents (25\%) in the poor category of family knowledge. From the results of the pretest and posttest, there was an increase in family knowledge about COVID-19, which was $19.4 \%$ from before.

This study is in line with research conducted by H. Mulyana, A. I. Mutiudin, A. I. Hidayatulloh, and B. Lutfi (8) which explained that there was a significant difference between the pretest and post-test. The formation of a person's actions is largely influenced by the knowledge he has. The results of education and health promotion activities can increase knowledge about preventing the occurrence of a disease problem in the community. The results of the education show that maternal awareness has increased from before and after education, $Z$ count is -4.146 and $p$-value is 0.000 . Mothers are expected to be able to apply the results of educational efforts in their daily activities so that the impact of being infected with COVID-19 on stunted children does not occur.

This research is also in line with research conducted by Nanang Saprudin, Aditia Puspa Negara, and Buggy Guntara who said that the results showed that there was an increase in knowledge and attitudes of mothers after being given health education. The results of the statistical test show the $p$-value of knowledge level $=0.0001<$ alpha (0.05) and the p-value of attitude $=0.0001<$ alpha (0.05) which means, there is an influence between HBM health education and mother's knowledge and attitudes in giving pentavalent immunization to children (15).

At the time of health education through the 6 dimensions of the HBM, data on the perception of pretest susceptibility (25\%) had a good sense of vulnerability, which means that mothers are aware of the ease with which they are exposed to the COVID-19 virus, meanwhile (27.8\%) others are in the category sufficient and those in the less category of (47.2\%). Some respondents said that I am not susceptible to this disease if my body feels good, and he will be vulnerable if his body feels not fine.

Then on the results of posttest research after HBM health education was carried out, data were obtained in a good category of $25 \%, 52.8 \%$ sufficient category, and $22.2 \%$ indicating less category. In the posttest results, there were still respondents who said that they were not susceptible to this disease.

The assessment of this vulnerability perception factor is seen from several assumptions by research subjects. These assumptions include an environment where there 
are many cases of COVID-19, all ages can be affected, all family members can also be affected and the assumption that not implementing health protocols makes it possible to be infected (9).

These results are in line with research conducted by Onoruoiza (14) which states that the perception of vulnerability actually refers to a subjective assessment of the risk of health problems. Individuals who believe that they have a low risk of disease are more likely to engage in unhealthy behavior and those who perceive that they are at high risk are more likely to engage in preventive behavior. The results of this study indicate that 97 people think they are vulnerable, 94 people do prevention well and only 3 people do prevention with enough and less good categories. There are also those who think they are not vulnerable but take good precautions even though in a very small scope (9).

In the results of the second point of HBM research, namely the perception of seriousness or danger in the pretest and posttest, the score (63.8\%) was in a good category and the category was less in number (36.2\%). Then the posttest results show that the perception of seriousness is in a good category (88.9\%) and in the less category (44.4\%). These results indicate an increase of $25.1 \%$ after health education.

The findings during health education showed that although most respondents thought they were serious about this virus and took good precautions, there were still some who thought that this virus would not cause any seriousness. This means that if the perception of seriousness is high, the respondents' prevention will be better. Vice versa, if the perception is getting smaller, the worse it will be in efforts to prevent it.

Research conducted by Lestari WRPL, Hidayah W, Sholiha M confirms the results of this study. Because the perceived seriousness of the disease causes a person to believe that the risk of this seriousness level is a threat to himself and his family, therefore a person will adopt action seeking treatment and prevention of the disease (11).

On the perception of the benefits of HBM, it was obtained that the pretest data was in a good category (55.6\%) and the less category (44.4\%). The posttest results showed an increase with data that the good category (66.7\%) was in the less category (33.3\%). As a result of this perception during health education, some respondents really understood the benefits of being obedient in maintaining and implementing health protocols. Benefits for himself and for other families to stay healthy and avoid COVID19. This perception is supported by the results of research conducted by Nurkholifah $\mathrm{S}$, Handiyani $H$ (13) which shows that the perceived benefits of hypertension prevention measures at most (90\%) are sufficient. Adolescents are also largely aware of the benefits 
of preventing hypertension, having the autonomy to determine whether preventive measures will be taken or not (13).

Then based on the results of the research on the perception of barriers, the pretest data showed a good category (55.6\%) and a less numbered category (44.4\%). The posttest results show that the perception of this barrier is in a good category (66.7) and the less category (33.3\%). In the results of research conducted by Mindayani S, Hidayat $H$ (12) stated that in the perception of these barriers in the good category fewer have good prevention behavior in HIV/AIDS transmission (9\%), while those who are not good (36\%) (11). This perceived barrier is a perceived obstacle referring to a person's belief in reality and the psychological cost of the behavior suggested by the Resource Center for Adolescent Pregnancy Prevention, 2007. This study is in line with the research of Wulandari WT, Rochliadi A, Arcana IM (17) and shows the results of the influence between perceived barriers and STI prevention behavior in FSW in Banjarsari Surakarta (11).

Then the results of the fifth HBM research point, namely healthy motivation, showed that the category (55.6\%) and the category less (44.4\%). The results of the post-test showed that the data in the good category amounted to (61.1\%), while the poor category (38.9\%). In this category, there is an increase in motivation to do our best to avoid the COVID-19 virus. In line with the research conducted by S. A. Agustina, the results showed that the coefficient of condom use was 0.19 , which means that the motivational variable in condom use has a positive effect on condom use. If there is an increase in motivation to use condoms by 1 point, then there will be an increase of 0.19 times the behavior of using condoms. This perception affects a person's behavior in using condoms. This is based on their belief in being able to prevent this behavior, the higher the confidence to always use condoms, the better the use of condoms in preventing STIS (16).

Based on the research on the last HBM point, the cue to act shows the pretest data in the good category (30.6\%), sufficient category (25\%), and poor category (44.4\%). Then the post-test results showed that the data were in a good category (36.1\%), moderate category $52.8 \%$, and poor category (11.1\%). In line with the research conducted by Mindayani S, Hidayat $\mathrm{H}(12)$, in the perception, it was found that the encouragement of good actions was more likely to have good preventive behavior in HIVIAIDS transmission (23\%) compared to those who were not good (22\%). Wulandari WT, Rochliadi A, Arcana IM (17) said there was a relationship between the drive to act and STI prevention behavior in FSW in Banjarsari Surakarta (11). Based on this perception, respondents said that they are ready, whatever the regulations that must be carried out to reduce the number of COVID-19 cases, which until now have not ended. They said they were ready to 
tighten health protocols such as wearing masks, maintaining distance, washing hands, not touching the face, and always thinking positively about whatever is happening at this time.

The bivariate results show that based on the pretest-posttest design method with statistical results using the Dependent T-test formula, the p-value of 0.000 is obtained which is smaller than the value of: 0.05 ( $p<0.05)$ which indicates that $\mathrm{HO}$ is rejected and $\mathrm{Ha}$ is accepted, it means that there is an influence between the Health Belief Model (HBM) Health Education on Family Knowledge About COVID-19 in Mothers with Stunting Children.

\section{Conclusion}

Based on the results of the research and discussion, it can be concluded that the description of family knowledge about COVID-19 before the Health Belief Model (HBM) health education for mothers with stunting children shows data that 13 families (36.1\%) have good knowledge, 7 families (19.5\%) have sufficient knowledge and 16 families (44.4\%) have less knowledge. The description of family knowledge about COVID-19 after HBM health education was carried out on mothers with stunting children showed data that 27 families (75\%) had good knowledge and 9 families (25\%) still lacked knowledge. There is a significant effect between the effect of HBM health education on family knowledge about COVID-19 in mothers who have stunting children with a p-value of 0.000 .

\section{Acknowledgement}

Our gratitude goes to all parties, especially to the respondents and the University of Bhakti Kencana Tasikmalaya for their support, both morally and materially.

\section{References}

[1] World Health Organization. WHO coronavirus (COVID-19) data dashboard. Geneva: World Health Organization; 2021. Available from: https://covid19.who.int/

[2] P. I., K. Covid-19, Sebaran kasus covid-19 di jawa barat. pikobar.jabarprov.go.id; 2021. Available from: https://pikobar.jabarprov.go.id/distribution-case

[3] G. T. P. P. C-19, sebaran covid-19 di kabupaten tasikmalaya. sigesit119.tasikmalaya.go.id; 2021 Available from: 
https://sigesit119.tasikmalayakab.go.id/web/index.php/profil/peta-sebaran-covid-19

[4] Mulyana H, Sansuwito TB, Nandang A. Relationships between social media news about Covid-19 and level of alertness on family with stunted children in Tasikmalaya City. KnE Life Sciences. 2021:391-401.

[5] Mulyana H, Hidayat F, Hidayanti R. Dampak stunting terhadap kecerdasan intelektual. JKIH Jurnal Kesehatan Indra Husada. 2021;9(1):102-10.

[6] Notoatmodjo S. Pendidikan dan perilaku kesehatan. Jakarta: Rineka Cipta; 2012.

[7] Hasaini A, Wahana H. Factors affecting health protocol compliance during the Covid19 pandemic: A literature review. JNHS (Journal of Nursing and Health Sciences). 2021;1(1):1-6.

[8] Mulyana H, Mutiudin Al, Hidayatulloh Al, Lutfi B. Edukasi kesehatan Covid-19 untuk meningkatkan kewaspadaan ibu yang mempunyai anak stunting. Jurnal Pengabdian Masyarakat Indonesia Maju. 2021;2(2):44-48.

[9] Attamimy HB, Qomaruddin MB. Aplikasi health belief model pada perilaku pencegahan demam berdarah dengue. Jurnal Promkes: The Indonesian Journal of Health Promotion and Health Education. 2018;5(2):245. doi: 10.20473/jpk.v5.i2.2017.245255

[10] Becker $\mathrm{MH}$. The health belief model and sick role behavior. Health education monographs. 1974;2(4):409-19.

[11] Lestari WRPL, Hidayah W, Sholiha M. Hubungan paritas dengan kejadian perdarahan post partum pada ibu bersalin. Jurnal Penelitian Kesehatan. 2015;5(1):1-6.

[12] Mindayani S, Hidayat $\mathrm{H}$. Risk factor analysis of HIV/AIDS transmission to loading workers in port of Padang City. Paper presented at: 4th International Symposium on Health Research (ISHR 2019); 2020 Feb 22. Atlantis Press.

[13] Nurkholifah S, Handiyani H. Nursing student's readiness and hope in preventing needle-stick injury. Paper presented at: 4th International Conference for Global Health (ICGH); Jakarta, Indonesia. 2019 Sep 1.

[14] Onoruoiza SI, Musa A, Umar BD, Kunle YS. Using health beliefs model as an intervention to non compliance with hypertension information among hypertensive patient. Int Organ Sci Res J Human Soc Sci. 2015;20(9):11-6.

[15] Saprudin N, Negara A, Guntara B. Pengaruh pendidikan kesehatan health belief model terhadap tingkat pengetahun dan sikap ibu dalam pemberian imunisasi pentavalen di desa wangkelang. JKIH. 2017;4(2):37-5.

[16] Agustina SA. Hubungan komponen health belief model dengan upaya pencegahan infeksi menular seksual pada ibu rumah tangga melalui penggunaan kondom. Hear. J. Kesehat. Masy. 2019;7(2):55-62. 
[17] Wulandari WT, Rochliadi A, Arcana IM. Nanocellulose prepared by acid hydrolysis of isolated cellulose from sugarcane bagasse. IOP Conference Series: Materials Science and Engineering. 2016;107(1):012045. 